\title{
SOCIAL RISKS AS A FACTOR OF REGULATION OF THE SYSTEM OF SOCIAL PROTECTION OF THE POPULATION IN UKRAINE
}

Formulation of the problem. According to modern methodological principles, the mechanism of regulation of social protection of the population (SPP) is based on the category of "social risk". This concept was introduced into scientific circulation in accordance with such international acts as: ILO Convention and Recommendation № 10 (1952) on minimum social security standards; № 128 (1967) on disability benefits, old age and in case of loss of a breadwinner; European Social Security Code (1964 and 1990); European Charter of the Fundamental Social Rights of Workers (1989), etc.

Risk is a measure of expected failure, the possibility of losing certain values or the occurrence of adverse events. From the point of view of social life, all risks are social, but distinguish purely social risks. They are considered as "measures of the expected consequence of a certain phenomenon, the occurrence of which is associated with the probability of loss or restriction of economic independence and social well-being of man" [1, p. 345]. They are associated with the danger of social deformations and disproportions in the functioning and development of man, society, state [2, p. 100].

Analysis of recent research and publications. In domestic theory and practice, the issue of assessment and prevention of social risks is covered in the works of N. Boretska, T. Boyarchuk, E. Libanova and other scientists. To create an effective system of SPP requires a comprehensive and systematic analysis of social risks, their qualitative assessment, measurement, forecasting.

The purpose of the article is to determine the impact of social risks on the state of social protection of citizens of Ukraine.

Presentation of the main research material. Social risks are considered the cornerstone of social protection, seen as its goal. They need to be taken into account to prevent the deterioration of social security conditions in general and the most vulnerable in particular. Social risks include the loss of a permanent source of income in the event of unemployment; disability due to illness, accident, old age, pregnancy, the need to care for children; death of the breadwinner, etc. These risks are massive, arise as a result of certain events that are known and have a permanent, predictable nature.
They usually depend little on the behavior of the individual and are determined mainly by social and economic conditions. The classification of social risks is important for the organization of the SPP system. Each country determines social risks based on the socio-economic situation, based on the norms of international conventions (ILO Convention № 102 and the European Social Security Code). According to this Code, social risks are divided into traditional and non-traditional $[2$, p. 46-49].

Traditional risks include loss or reduction of income due to objective circumstances: illness, unemployment, old age, occupational injury, occupational disease, child support, pregnancy and childbirth, disability, loss of breadwinner. They are typical and have the highest probability in everyone's life. They are taken into account when providing social benefits through the social insurance system. In Ukraine, traditional risks are reflected in the Law of Ukraine on Compulsory State Social Insurance (Article 26) [3].

According to the methodological approaches to the concepts of "human capital" and "social protection" recommended by international organizations in the context of globalization, it is proposed to expand the list of life circumstances that disrupt a person's normal life and which he can not overcome alone. Such social risks are considered unconventional. In European countries, these include support for families with children, upbringing and education of children, care for sick children and parents, assistance for the construction and maintenance of housing, financial support for mothers for the period of interrupted vocational education for up to five years per child, poverty etc.

In countries where active family policy is pursued by equalizing family expenses, family social benefits are provided outside the social insurance system through taxes. In Ukrainian legislation, non-traditional social risks are regulated by a number of laws. They are most fully formulated in the Law of Ukraine "On Social Services" [3]. In order to measure social risks, a mechanism of social expertise is used. It provides for the development, comparison and compliance with the require- 
ments of state social standards and regulations based on risk monitoring and assessment of social potential.

From a legal point of view, the Ministry of Social Policy of Ukraine is a central executive body, whose activities are directed and coordinated by the Cabinet of Ministers of Ukraine and which ensures the formation and implementation of state policy in labor and social policy, social protection, volunteering, family and children, rehabilitation and recreation of children, adoption and protection of children's rights, prevention of domestic violence, social protection of war veterans and participants in the anti-terrorist operation, including providing their psychological rehabilitation, spa treatment, technical and other means of rehabilitation, housing, provision of educational services, organization of funerals, social and professional adaptation of discharged servicemen, persons discharged from military service and participants in the anti-terrorist operation. Since the objects and subjects of social policy are on the one hand state institutions, and on the other - the population, it is advisable to consider a comprehensive system of social protection as a state institution of care for the most vulnerable (Fig. 1).

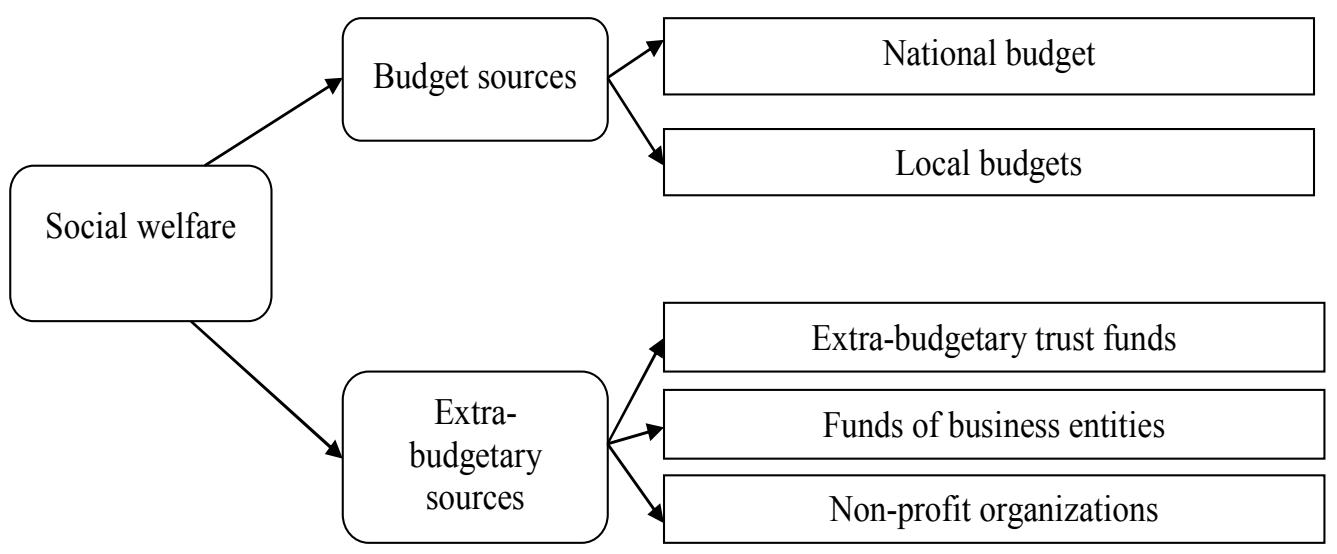

Fig. 1. Types of sources of funding for social security

(formed by the authors based on source [4])

To see the real amount of expenditures on social protection and social security in Ukraine, it is necessary to identify those that in practice are financed from other budget expenditures, but in fact are aimed at addressing certain issues in the field of social protection and social security.

The main sources of financial resources in Ukraine are funds accumulated as a result of taxes and insurance contributions to the state and local budgets, state funds of compulsory state social insurance, non-governmental organizations that provide social insurance (insurance companies, private pension funds). At the same time, a significant part of social expenditures is carried out at the expense of household incomes and social expenditures of employers, which are carried out without paying insurance contributions to any specific social insurance funds.

Thus, the main sources of funding for social protection in most countries are: 1) contributions paid by employees and employers on a mandatory or voluntary basis to public or private social insurance funds; 2) tax revenues that form part of total state revenues; 3 ) investment income from the placement of accumulated funds of public or private social insurance funds in the financial markets; 4) private funds. Equally important is the use of available financial resources.

The social protection system covers all types of public and private social programs that are aimed at supporting various categories of the population in the event of such a need under the influence of social risks. A significant problem in the financial provision of social protection in Ukraine is that the state directs a significant part of financial resources to support the population that does not need such assistance, which negatively affects the living standards of the most vulnerable. In addition, the national social protection system is characterized by the presence of a large number of in-kind transfers, the share of which is about $13 \%$.

Despite the significant size and growing trend of social spending, many social programs and benefits in Ukraine are extremely poorly funded. Some types of social benefits in some years were not funded at all or their size was reduced by law, as the State Budget of Ukraine did not have enough funds for this (for example, childbirth assistance, etc.). The dispersion of public financial resources and the difficult economic situation in the country directly affect the size of basic state social standards (subsistence level, minimum pension, minimum wage). The dynamics of these indicators are shown in table 1.

The analysis of the data in Table 1 showed that the size of the minimum pension in Ukraine is many times less than the value of the minimum consumer basket, which is the basis for determining the subsistence level and, in fact, the subsistence level itself. Such an imbalance indicates an extremely low level of social protection of the country's population. 
Dynamics of the size of the main state social standards of Ukraine in 2014-2019

(compiled by the authors based on sources [5])

\begin{tabular}{|l|c|c|c|c|c|c|}
\hline \multirow{2}{*}{\multicolumn{1}{|c|}{ Indexes }} & \multicolumn{7}{c|}{ Years } \\
\cline { 2 - 7 } & 2014 & 2015 & 2016 & 2017 & 2018 & 2019 \\
\hline Minimum pension & 949 & 949 & 1074 & 1295 & 1409 & 1564 \\
\hline Minimum salary & 1218 & 1271 & 1438 & 3200 & 3723 & 4173 \\
\hline Subsistence level & 1176 & 1227 & 1376 & 1604 & 1745 & 1936 \\
\hline Minimum consumer basket & 1052 & 1129 & 1169 & 1446 & 1745 & 1936 \\
\hline Average monthly salary & 3470 & 5230 & 6475 & 7105 & 8867 & 10783 \\
\hline
\end{tabular}

The social protection system of Ukraine has a number of problems that need to be addressed immediately: non-transparent legal framework, the presence of a large number of ineffective social benefits, imperfect funding system and bureaucracy in social protection bodies.

Budget financing of social security in Ukraine also has a number of problems, especially at the local level. Improving the financial security of social protection is impossible without strengthening the financial base and increasing the financial independence of local budgets. The state system of financing social benefits, privileges and assistance remains one of the main components of the general and comprehensive system of social protection of Ukraine and needs to be reformed, changes in approaches to organizational principles of providing and financing state social assistance, introduction of new ways and methods.

Material resources will allow to work more effectively for the benefit of those in need of social protection. 41.5 times in 2019, compared to 2014, increased state support for local and regional development in addition, in 2019 a subvention for the construction, reconstruction, repair and maintenance of public roads of local importance in the amount of 14.7 billion. UAH [6].

Let's analyze the unemployment rate in Ukraine in recent years. The global financial crisis, the occupation of Crimea and the situation in the east of the country have caused significant damage to Ukraine. That is why the largest reductions in employment at the beginning of the crisis were in sectors such as industry and construction.

Over the past four years, the unemployment rate in Ukraine has fallen by $0.5 \%$. Such data were published in January 2020 by the State Statistics Service of Ukraine [7].

During the quarantine, which lasts from March 2020, according to the Decree of the Cabinet of Ministers of Ukraine of March 11, 2020 № 211, due to the threat of spreading a new coronavirus infection, the level of real unemployment in Ukraine has increased. Thus, according to the Chamber of Commerce and Industry, in the first two weeks of quarantine the number of unemployed increased by 500-700 thousand, and in the next two weeks - in April - another 500-600 thousand people were added. In general, at least 2.5-2.8 million people in Ukraine are unemployed today. According to the estimates of the Chamber of Commerce and Industry of Ukraine, the unemployment rate today is $13.7-15.4 \%$. This is the highest figure for the last 15 years [6].

Unemployment is a macroeconomic problem caused by such factors as structural changes (intersectoral, intra-industry, regional) in the economy (e.g., introduction of new technologies, curtailment of production in traditional industries, closure of technically backward enterprises), declining economic development, seasonal fluctuations in production, insufficient aggregate demand, inflation, imperfect labor legislation, low level of vocational training and retraining, inadequate level of employment programs and demographic processes [8].

Consider the dynamics of the number of unemployed and the unemployment rate in Ukraine for 20162020 (Table 2). According to the State Statistics Service of Ukraine, the number of unemployed is steadily declining every year from January to September, and in 2020 the number of unemployed has risen sharply.

Table 2

Dynamics of the number of unemployed and the unemployment rate in Ukraine (formed by the authors on the basis of the processed source [6])

\begin{tabular}{|c|c|c|c|}
\hline \multirow{2}{*}{ Years } & \multicolumn{3}{|c|}{ Unemployed population } \\
\cline { 2 - 4 } & $\begin{array}{c}\text { on average, thousands } \\
\text { of people }\end{array}$ & $\begin{array}{c}\text { \% to the economically } \\
\text { active population }\end{array}$ & $\begin{array}{c}\text { registered } \\
\text { unemployed }\end{array}$ \\
\hline 2016 & 1677,5 & $9,7 \%$ & 407,2 \\
\hline 2017 & 1697,3 & $9,9 \%$ & 352,5 \\
\hline 2018 & 1577,6 & $9,1 \%$ & 341,7 \\
\hline 2019 & 1486,9 & $8,6 \%$ & 338,2 \\
\hline 2020 & $2500,0-2800,0$ & $13,7 \%-15,4 \%$ & 900,0 \\
\hline
\end{tabular}


In 2016, for 9 months, 341.5 thousand people found a job, thousands of people who were unemployed at the beginning of the year, in 2017 this trend continued: in September there were 303 thousand fewer unemployed than in January [9], in 2018 - 417.3 thousand people thousand people who were unemployed at the beginning of the year [10]. In 2020, from the beginning of the quarantine (from March 12 to July 31, 2020), 395 thousand people received the status of unemployed, which is $71 \%$ more than in the same period last year.

However, it should be noted that recently the growth in the number of registered unemployed has stopped. Thus, in April, 149 thousand people received the status of unemployed, in May their number was 97 thousand people, in June - 75 thousand people, in July - 68 thousand.

During the quarantine, the specialists of the employment centers do not stop selecting suitable vacancies for the unemployed and qualified staff for employers. From March 12 to July 31, 2020, 222 thousand citizens managed to find work, including 151 thousand unemployed.
The crisis caused by the coronavirus infection has, without exaggeration, made significant adjustments to the Ukrainian labor market. In the field of employment, there was a significant decrease in the number of vacancies, along with an increase in the number of unemployed citizens. As of the beginning of August, 8 unemployed people applied for one job.

Among the main problems in the field of social protection of the population of Ukraine, which require immediate solution, are the following: extremely high level of state participation in the field of social protection, extremely weak participation in its functioning population; extremely rapid growth in the cost of services provided by health care, education, culture, which does not correspond to their quality; inefficiency of budget management of available financial resources both by the main managers, and separate social establishments; lack of funds to finance measures in the field of social protection.

The financial security of social protection should also be analyzed in terms of achieving its goals. Fig. 2, 3 show the dynamics of wage arrears in Ukraine and the dynamics of real disposable income of the population of Ukraine.

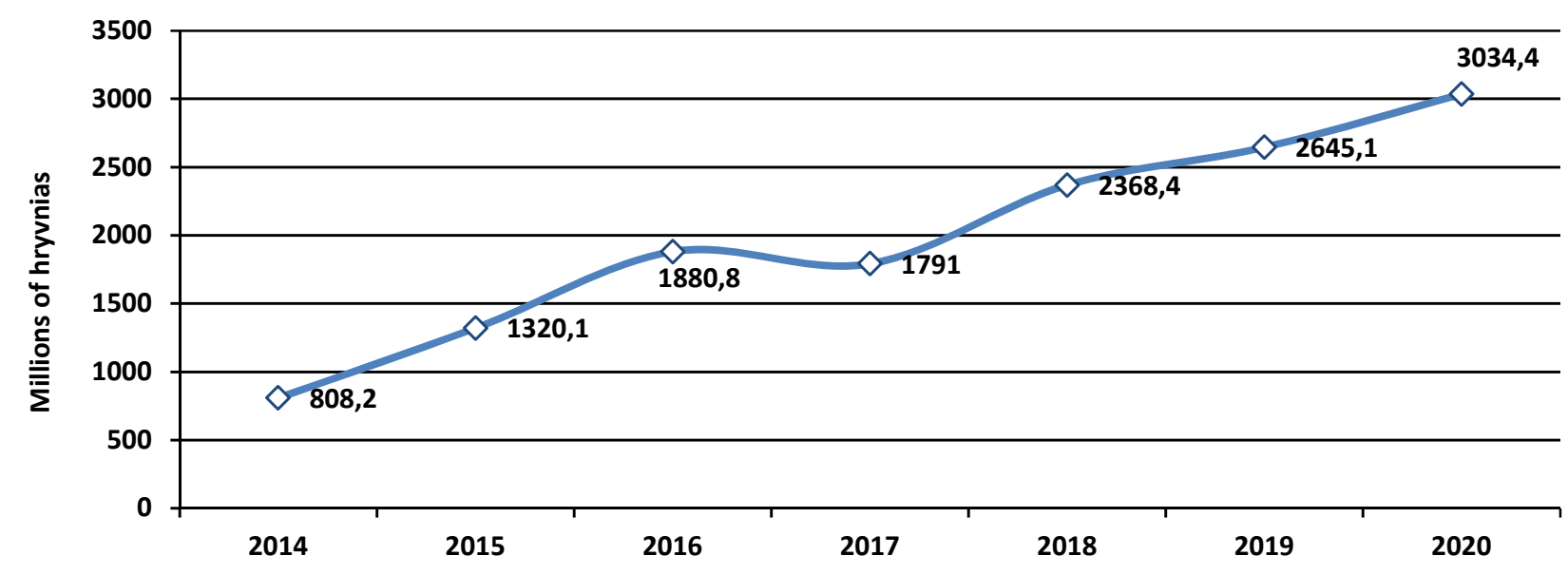

Fig. 2. Dynamics of wage arrears in Ukraine

(compiled by the authors based on source [6])

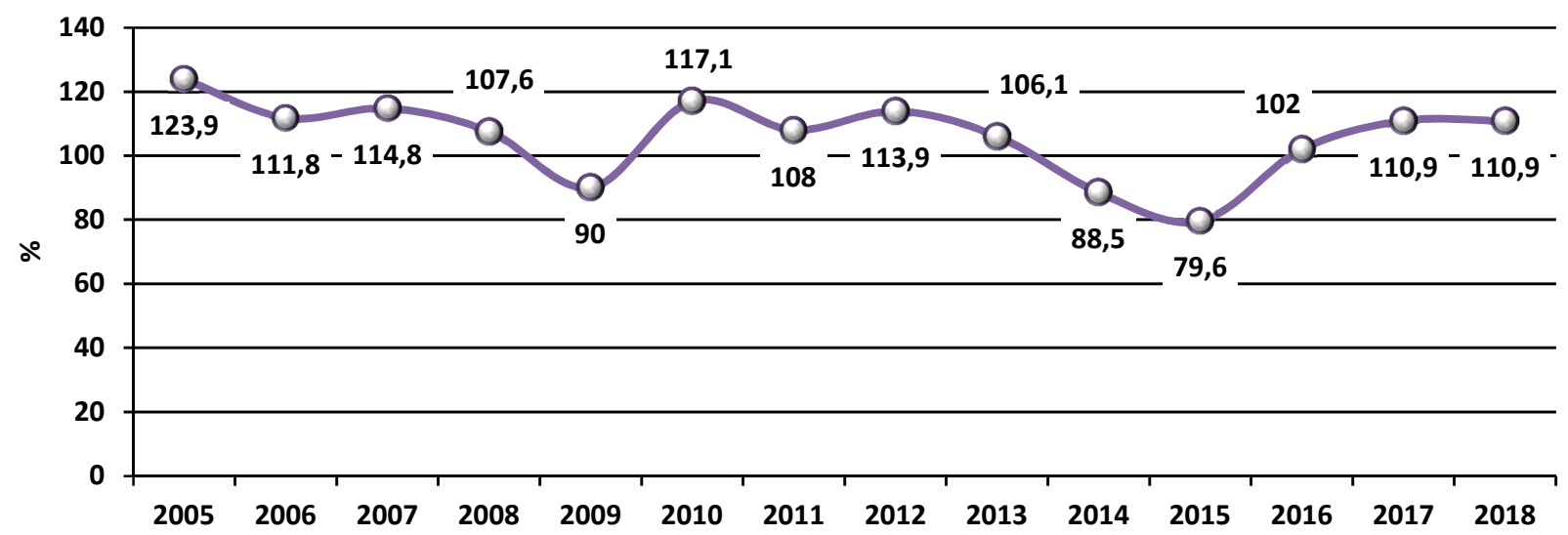

Fig. 3. Dynamics of real disposable income of the population of Ukraine (compiled by the authors based on source [6]) 
It should be noted that each individual social program provides for the achievement of its specific goals, which allows to assess the effectiveness of their funding not only in the country as a whole, but also in individual regions. At the same time, all the goals of individual social programs provide for the achievement of the main goals of the social protection system: reducing poverty, increasing incomes, reducing inequality and increasing life expectancy.

In general, current trends in the financial provision of social protection in Ukraine do not meet the challenges posed to society by the current socio-economic and demographic situation, which negatively affects both the level of funding and its effectiveness. Further development of social protection in Ukraine is possible only under the condition of deep structural reorganization as the social protection system itself (reduction of social benefits and privileges; increase of targeting; reduction of the number of in-kind transfers, etc.), and the basic conditions and principles of financing (expanding the share of private funds; increasing funding for social programs based on the cumulative principle; increasing the monetization and targeting of social benefits, etc.).
Today in Ukraine the following strategic directions of social policy development have been identified:

- increasing attention to the demographic policy of the state, which will perform the function of regulating the psychological propensity of people to a particular demographic behavior, which at the same time will need social protection and help solve a number of social policy issues;

- creation of ecologically and socially safe living conditions;

- protection of citizens from inflation through timely income indexation;

- limiting unemployment and stimulating employment; fits;

- repayment of arrears of wages and social bene-

- development of social infrastructure, creation of conditions for upbringing, education, spiritual development of children, youth, etc. [11]. Assessing the impact of traditional and non-traditional risks listed in Table 3 on the social security of the individual, it can be noted that almost all of them affect, and often significantly affect the well-being of citizens.

Table 3

Respondents' assessment of the degree of impact of traditional and non-traditional social risks on the social protection of citizens (compiled by the authors based on sources [4])

\begin{tabular}{|l|c|c|c|c|c|}
\hline & $\begin{array}{c}\text { Signifi- } \\
\text { cantly } \\
\text { affects }\end{array}$ & Affects & $\begin{array}{c}\text { Indirectly } \\
\text { affects }\end{array}$ & $\begin{array}{c}\text { Perhaps } \\
\text { affects, and per- } \\
\text { haps and does } \\
\text { not affects }\end{array}$ & $\begin{array}{c}\text { Not } \\
\text { affects }\end{array}$ \\
\hline The possibility of disease & 156 & 170 & 54 & 39 & 8 \\
\hline Income level & 204 & 184 & 28 & 8 & 3 \\
\hline Number of children in the family & 129 & 194 & 56 & 31 & 16 \\
\hline Loss of a breadwinner & 258 & 121 & 21 & 14 & 15 \\
\hline Retirement age & 73 & 201 & 88 & 54 & 15 \\
\hline The possibility of work-related injuries & 146 & 162 & 59 & 47 & 13 \\
\hline Homelessness (possibility of insecurity) & 205 & 140 & 46 & 20 & 19 \\
\hline Professional qualification level & 85 & 183 & 102 & 40 & 19 \\
\hline Employment & 91 & 217 & 86 & 28 & 5 \\
\hline $\begin{array}{l}\text { Guaranteed quality of goods and services } \\
\text { in the relevant markets }\end{array}$ & 70 & 152 & 110 & 75 & 19 \\
\hline Security from criminal & 99 & 133 & 110 & 68 & 15 \\
\hline State social guarantees & 115 & 176 & 78 & 43 & 15 \\
\hline Civil rights and freedoms & 83 & 164 & 94 & 60 & 22 \\
\hline $\begin{array}{l}\text { How the current financial and economic } \\
\text { crisis is affecting your well-being }\end{array}$ & 221 & 132 & 56 & 30 & 69 \\
\hline
\end{tabular}

The problem is that most of the factors that cause social risks are poorly predictable, incompletely controlled. Social risks can be quantified only by the probability of their occurrence.

Thus, the progressive and dynamic development of Ukraine today should focus on the socialization of the economic system with full consideration of the needs, interests of the population, its incentives for productive work to realize their own professional potential, com- prehensive development, receiving a decent reward for work.

The priority of solving social problems logically follows from the objective need to create conditions for dynamic, balanced socio-economic development of the regions of Ukraine, their optimal integration into the world economic space, which puts forward new requirements for the process of population reproduction, formation of social and labor resources, relations, develop- 
Y. Bolotina, N. Steshenko, V. Tkachenko, V. Chalenko

ment of all spheres of life of the population and its main component - labor. In this regard, it is necessary to transform the functions of the state in the management of social development.

The evolution of modern methods of state regulation should take place in the direction of increasing their flexibility, shifting the emphasis from regulatory and restrictive measures to purely stimulating ones.

Conclusions. Social processes, including social risks, are characterized by incompleteness, vagueness and uncertainty and do not allow a sufficient degree of formalization. Uncertainty arises, first, in the presence of a significant number of social risk measurements. Secondly, it is also present in the case when some qualitative characteristics are fuzzy "blurred" in nature.

One of the significant obstacles to the effective implementation of social policy in our country is the insufficient level of its financial security in combination with irrational planning, distribution and inefficient use of available financial resources. Official statistics show the existence in the last decade of a stable, pronounced trend of budget financing of social expenditures on a residual basis with a simultaneous annual decrease in their share in the structure of expenditures of the consolidated budget of Ukraine and GDP.

This contradicts the provisions of the Constitution, which proclaims the social orientation of the economy of our state, the main duty of which is to affirm and ensure human rights and freedoms as the highest social value. In this regard, an important national task is to find effective mechanisms for planning and implementing social spending, taking into account the best foreign experience, which would allow to fully implement the priorities of social policy.

\section{Literature}

1. Социальная энциклопедия / за ред. А. П. Горкина и др. Москва: БРЭ, 2000. 438 с. 2. Борецька Н. П. Соціальний захист населення на сучасному етапі: стан і проблеми. Донецьк: Янтра, 2001. 352 с. 3. Закон України «Про соціальні послуги». Голос Украӥни. 2003. 22 лип. С. 1. 4. Сташків Б. І. Право соціального забезпечення. Загальна частина: навч. посіб. Чернігів: ПАТ «ПВК» «Десна», 2016. 692 с. 5. Офіційний сайт Міністерства фінансів України. URL: http://minfin.gov.ua. 6. Державна служба статистики України. URL: http://ukrstat.gov.ua. 7. Офіційний веб-сайт Державної казначейської служби України. URL: http://treasury. gov.ua. 8. Зайщева I. С. Проблеми зайнятості та безробіття в Україні та країнах Європейського Союзу. Уnравління розвитком. 2016. № 11. С. 125-130. 9. Гітіс Т. П., Чемерис Є. Т., Антонова В. I., Носаньова А. С. Дослідження сучасного рівня соціального захисту населення в Україні. Економічний вісник Донбacy. 2020. № 1 (59). C. 116-122. doi: 10.12958/18173772-2020-1(59)-116-122. 10. Дюк А. А. Формування системи видатків державного бюджету та їх оптимізація. Ефективна економіка. 2018. С. 56-63. 11. Лисяк Л. В. Фінансове забезпечення соціального захисту населення в Україні: проблеми та перспективи. Вісник
Дніпропетровського університету. Серія «Економіка». 2017. С. 23-30.

\section{References}

1. Gorkina, A. P. et al. (Eds.). (2000). Social encyclopedia. Moscow, BRE [in Russian].

2. Boretska, N. P. (2001). Sotsialnyi zakhyst naselennia na suchasnomu etapi: stan i problemy [Social protection of the population at the present stage: state and problems]. Donetsk, Yantra. 352 p. [in Ukrainian].

3. Zakon Ukrainy «Pro sotsialni posluhy» [Law of Ukraine "On Social Services"]. (2003). Holos Ukrainy Voice of Ukraine, 22 Jul., p. 1 [in Ukrainian].

4. Stashkiv, B. I. (2016). Pravo sotsialnoho zabezpechennia. Zahalna chastyna: navch. posib. [The right to social security. General part]. Chernihiv, PJSC «PVK» «Desna» [in Ukrainian].

5. Ofitsiinyi sait Ministerstva finansiv Ukrainy [Official site of the Ministry of Finance of Ukraine]. (n.d.). minfin.gov.ua. Retrieved from http://minfin.gov.ua [in Ukrainian].

6. Derzhavna sluzhba statystyky Ukrainy [State Statistics Service of Ukraine]. (n.d.). ukrstat.gov.ua. Retrieved from http://www.ukrstat.gov.ua/ [in Ukrainian].

7. Ofitsiinyi veb-sait Derzhavnoi kaznacheiskoi sluzhby Ukrainy [Official website of the State Treasury Service of Ukraine]. (n.d.). treasury.gov.ua. Retrieved from http://treasury.gov.ua [in Ukrainian].

8. Zaitseva, I. S. (2016). Problemy zainiatosti ta bezrobittia v Ukraini ta krainakh Yevropeiskoho Soiuzu [Problems of employment and unemployment in Ukraine and the countries of the European Union]. Upravlinnia rozvytkom - Development management, 11, pp. 125-130 [in Ukrainian].

9. Gitis, T. P., Chemerys, Ye. T., Antonova, V. I., Nosanyova, A. S. (2020). Doslidzhennia suchasnoho rivnia sotsialnoho zakhystu naselennia $\mathrm{v}$ Ukraini [Study of the Current Level of Social Protection of the Population in Ukraine]. Ekonomichnyi visnyk Donbasu - Economic Herald of the Donbas, 1 (59), pp. 116-122. doi: 10.12958/ 1817-3772-2020-1(59)-116-122 [in Ukrainian].

10. Diuk, A. A. (2018). Formuvannia systemy vydatkiv derzhavnoho biudzhetu ta yikh optymizatsiia [Formation of the system of state budget expenditures and their optimization]. Efektyvna ekonomika - Efficient economy, Vol. 3, pp. 56-63 [in Ukrainian].

11. Lysiak, L. V. (2017). Finansove zabezpechennia sotsialnoho zakhystu naselennia $\mathrm{v}$ Ukraini: problemy ta perspektyvy [Financial provision of social protection of the population in Ukraine: problems and prospects]. Visnyk Dnipropetrovskoho universytetu. Seriia «Ekonomika»Bulletin of Dnipropetrovsk University. Economics series, pp. 23-30 [in Ukrainian].

Болотіна Є. В., Стешенко Н. Л., Ткаченко В. О., Чаленко В. П. Соціальні ризики як чинник регулювання системи соціального захисту населення в Україні

У статті здійснено класифікацію соціальних ризиків на традиційні і нетрадиційні та їх вплив на регулювання системи соціального захисту населення в Україні. Виявлено сучасні проблеми фінансування сфери 
соціального захисту населення в Україні та окреслено шляхи їх подолання. Наведено динаміку заборгованості з виплати заробітної плати в Україні та динаміку реального наявного доходу населення України за 20052018 роки. Доведено, що однією із вагомих перешкод на шляху ефективної реалізації в нашій країні соціальної політики $є$ недостатній рівень ії фінансового забезпечення у поєднанні 3 нераціональним плануванням, розподілом і неефективним використанням наявних фінансових ресурсів. Представлено оцінку респондентами ступеня впливу традиційних і нетрадиційних соціальних ризиків на соціальну захищеність громадян. Визначено, що поступальний та динамічний розвиток України сьогодні повинен орієнтуватися на соціалізацію економічної системи 3 найповнішим урахуванням потреб, інтересів населення, його стимулів до продуктивної трудової діяльності для реалізації власного професійно-кваліфікаційного потенціалу, всебічного розвитку, одержання гідної винагороди за результати праці.

Ключові слова: соціальній захист, соціальні ризики, заробітна плата, безробітне населення, місцеві бюджети, соціальна політика.

Bolotina Ye., Steshenko N., Tkachenko V., Chalenko V. Social Risks as a Factor of Regulation of the System of Social Protection of the Population in Ukraine

The article classifies social risks into traditional and non-traditional and their impact on the regulation of the social protection system in Ukraine. The modern problems of financing the sphere of social protection of the population in Ukraine are revealed and the ways of their overcoming are outlined. The dynamics of arrears of wages in Ukraine and the dynamics of real disposable income of the population of Ukraine for 2005-2018 are presented. It is proved that one of the significant obstacles to the effective implementation of social policy in our country is the insufficient level of its financial support in combination with irrational planning, distribution and inefficient use of available financial resources. Respondents' assessment of the degree of impact of traditional and non-traditional social risks on the social protection of citizens is presented. It is determined that the progressive and dynamic development of Ukraine today can focus on the socialization of the economic system with full consideration of the needs, interests of the population, its incentives for productive work to realize their own professional potential, comprehensive development, receiving a decent reward for work.

Keywords: social protection, social risks, wages, unemployed population, local budgets, social policy.

Болотина Е. В., Стешенко Н. Л., Ткаченко В. О., Чаленко В. П. Социальные риски как фактор регулирования системы социальной защиты населения в Украине

В статье осуществлена классификация социальных рисков на традиционные и нетрадиционные и их влияние на регулирование системы социальной защиты населения в Украине. Выявлены современные проблемы финансирования сферы социальной защиты населения в Украине и очерчены пути их преодоления. Приведена динамика задолженности по выплате заработной платы в Украине и динамика реального имеющегося дохода населения Украины за 2005-2018 годы. Доказано, что одним из весомых препятствий на пути эффективной реализации в нашей стране социальной политики является недостаточный уровень ее финансового обеспечения в сочетании с нерациональным планированием, распределением и неэффективным использованием имеющихся финансовых ресурсов. Представлена оценка респондентами степени влияния традиционных и нетрадиционных социальных рисков на социальную защищенность граждан. Определено, что поступательное и динамическое развитие Украины сегодня должно ориентироваться на социализацию экономической системы с наиболее полным учетом нужд, интересов населения, его стимулов к продуктивной трудовой деятельности для реализации собственного профессионально-квалификационного потенциала, всестороннего развития, получения достойного вознаграждения за результаты труда.

Ключевые слова: социальная защита, социальные риски, заработная плата, безработное население, местные бюджеты, социальная политика.

Received by the editors: 04.11 .2020

and final form 29.12.2020 